\title{
Strategic Approach to Nation Branding: A Case of the Nigeria Brand
}

\author{
Edith Onowe Odia $^{1} \&$ Felix Osaiga Isibor ${ }^{1}$ \\ ${ }^{1}$ Department of Business Administration, Faculty of Management Sciences, University of Benin, Nigeria \\ Correspondence: Edith Onowe Odia, Department of Business Administration, Faculty of Management \\ Sciences, University of Benin, P.M.B 1154, Benin City, Edo State, Nigeria. Tel: 234-807-922-1107. E-mail: \\ edyy2002ng@yahoo.com
}

Received: December 23, 2013

Accepted: Feburary 13, $2014 \quad$ Online Published: February 21, 2014

doi:10.5539/ijbm.v9n3p204

URL: http://dx.doi.org/10.5539/ijbm.v9n3p204

\begin{abstract}
This study examines the current image of the Nigeria brand by reviewing the existing literature. The review was done on the basis of the key determinants of a nation brand image. The findings from the review identified areas of strength to be in telecommunications, abundance of raw materials, large population and hospitality while weaknesses were observed in the areas of energy, security, corruption, and education. A nation brand strategic management (NBSM) model was developed and applied on the Nigeria brand with a view to building its image. In addition, a framework of brand vectors for measuring a nation's brand image was formulated to exemplify effective perception audit, a critical stage in nation branding process.
\end{abstract}

Keywords: brand image, brand vectors, nation brand, sub-brands, strategic management

\section{Introduction}

A country's reputation determines the way people inside and outside the country feel and relate to it. In today's highly competitive marketplace, country image has become a critical success factor and yet very difficult to build and sustain. As competition becomes more intense and the marketplace more crowded, consumers, tourists, immigrants and investors tend to depend more on the country's reputation than on its actual attributes in making buying, travelling and investment decisions. Many nations the world over have now realised the significance of country branding. For example, Leonard (1997) wrote of the compelling need to rebrand Britain when he observed that there was a gulf between the reality of Britain as a highly creative nation and the world's mental model of it as a backward-looking Island immersed in its heritage. In a similar argument on the need to rebrand Canada, Ferguson (2001) remarked that no nation wants to remain anonymous. Rather, every country wants to develop a distinct and winning brand with positive multifaceted attributes for economic growth and world influence. Brymer (2003) argues that with the emergence of the global market, abundant opportunities abound, but countries with unknown or poor reputation will be marginalized. The observation made by Brymer (2003) about 'unknown or poor reputation' seems to describe the condition of Nigeria and most developing countries. Anholt (2007, p. 121) commenting on the state of Nigeria remarked that:

The significance of reputation for places such as Lagos and Nigeria is not trivial. If their image is entirely composed of negative elements-such as crime, war, poverty, disease or corruption-then it is unlikely that the city or the country will be able to attract many tourists, foreign investors, trading partners or even consumers for locally produced products.

Nigeria, with its enormous human and material resources is still grappling with myriads of problems such as bribery and corruption, advance fee fraud, unemployment, poor infrastructure, poor work ethics, poor educational, agricultural and health systems, tribal and religious unrests, insecurity, poverty and hunger (Nworah, 2007). In his view, the negative effect of image erosion has placed Nigeria in a disadvantaged position in the world market.

The former Minister of Information and Communication, Akunyili (2009, p. 20) also recognised the need to do something positive about Nigeria's sagging image when she stated,“... our image, especially in and outside this country, is highly battered. Outside this country, in particular, the perception of Nigeria and Nigerians is so bad that every Nigerian is regarded as a fraudster and criminal. We are never even given the benefit of the doubt".

The issue of rebranding Nigeria has gained much attention in the recent times because of its seeming negative image. A number of efforts have been made by the government to reposition the image of the Nigeria brand. The 
first major attempt was the launching of Heart of Africa Project (HOA) under the Obasanjo administration in 2004. The second major attempt was during Yar' Adua government in 2009, when Prof. Dora Akunyili launched 'The Rebrand Nigeria Campaign' through 'Good People, Great Nation'. One of the reasons adduced for HOA project's failure was that it was first launched overseas neglecting the internal marketing mechanism (Nworah, 2007; Ujiagbedion, 2008). In addition, is the omission of the fundamental step of image audit before the launching of HOA project (Nworah, 2007). A critical analysis of the second attempt revealed the gap of perception audit which also characterized HOA. For this reason, Fasure (2009) described the second rebranding project as 'Good Salesman with Bad Product'.

Our goal in this study is to determine the current image of the Nigeria brand by reviewing the existing literature. The rest of the work is structured as follows: the concept of nation branding, the Nigeria brand attributes; the proposed strategic model for managing nation brand image and its application to the Nigeria brand.

\section{Literature Review}

\subsection{Concepts and Theories in Brand Management}

Branding is a management tool traditionally used by company managers to create meaningful differentiation to achieve competitive advantage in the market place. Brand management is the process of planning, managing and coordinating strategy for specific brand. Managers' activities with respect to brand management include market analysis, targeting, positioning strategy, performance analysis and strategy adjustment, identification of new product needs and coordination of marketing activities (Cravens \& Piercy, 2006). The American Marketing Association conceptualizes a brand as a name, symbol, term or blend or mixture of them which differentiate the goods and services of one seller or a group of sellers from those of competition. In the view of Dinnie (2008), the scope of branding has incrementally gone beyond its application to simple products through to services, companies and organizations to include cities, nations and regions. The evolution of nation branding is traced to the interaction between academic fields of national identity and country of origin with the context of globalization (Dinnie, 2008).

Anholt (2007) distinguished between four aspects of a brand. They are brand identity, brand image, brand purpose and brand equity. Brand identity is "a unique set of brand association that the brand strategist aspires to create or maintains" (Aakar 1996, p. 68). It represents what the brand stands for and promise. Identity refers to what something truly is (Dinnie, 2008). Roll (2006) suggests the following points for consideration when formulating brand identity: Brand visions (future direction for the brand); Brand scope (market segments and product categories the brand can serve); Brand positioning (the place that the brand strives to occupy in customer's mind); Brand personality (brand character that helps the customer to connect emotionally with the brand) and Brand essence (the soul and heart of the brand, its uniqueness and what it stands for). Determining the brand identity strategy is a very important strategic initiative. According to Cravens and Piercy (2006), brand identification should span a long time horizon, providing a foundation for developing brand equity.

Image according to Concise Oxford Dictionary, is the general impression that a person, organization, or product presents to the public and a mental representation. It refers to how something is perceived. Jaffe and Nebenzahl (2001) defined country image as the impact that generalizations and perceptions about a country have on a person's evaluation of the country's products and/or brand. Following Riezebos (2003), a nation's brand image is a subjective mental picture shared by a group of people about the country. Brand purpose may be referred to as corporate culture, which Anholt (2007) conceives as the internal equivalent of brand image. It is the shared values, common purpose of organizational members. It is living the brand, and process of internalizing brand values; may also be referred to as power of shared goals.

Brand equity measurement is critical in strategic brand management. Effective strategic brand management requires understanding brand equity and to evaluate its impact when making brand management decision. Brand equity is a "set of brand assets and liabilities linked to a brand, its name and symbol that adds or subtract from the value provided by a product or services" (Aakar, 1991, p. 15). Aakar (1991) proposed the following measures as means of capturing all relevant aspects of brand equity: loyalty; perceived quality/leadership measures; associations/differentiation (perceived value, brand personality, organization/association); brand awareness and market behaviour (market share). Brand identity, image, purpose and equity have often been used in the context of product, service and corporations (PSC). However, these constructs are transferable to the context of nation branding (Anholt, 2007; Dinnie, 2008). Dinnie (2008) defined the Asset-Based Nation Brand Equity (NBEQ) as comprising internal (innate or natured) and external (vicarious or disseminated) assets or liabilities of the nation. Innate assets are enduring elements of national identity: iconography, landscape (cities) and culture. While the nurtured assets are: internal buy-in and support for the arts and loyalty levels. The 
vicarious assets are made up of country image perceptions, portrayal in popular culture and the disseminated assets include brand ambassadors, the diaspora, and branded exports.

We have examined brand in its traditional context, what is then a nation brand? A nation brand is defined as "the unique, multi-dimensional blend of elements that provide the nation with culturally grounded differentiation and relevance for all of its target audiences" (Dinnie, 2008, p. 15). Anholt (2007) recognizing the multi-facets nature of the nation brand, conceptualized it in his 'Nation Brand Hexagon' theory as made up of six components namely: governance, investment, exports, tourism, culture and people. For Nworah (2007, p. 45), nation branding is "the process whereby a town, region, country (place) actively seeks to create a unique and competitive identity for itself, with the aim of positioning it internally and internationally as a good destination for trade, tourism and investments." For us, nation branding is the process of building and managing a country's identity and image distinctly to attract and satisfy the needs of internal and external stakeholders, visitors and investors.

\subsection{Strategic Models for Nation Branding}

We present management models relating to products, services and corporations are presented before those of destination brands. First, we start with strategic brand management model by Aaker (1996). He developed a framework of strategic brand management process consisting of set of inter-related initiatives. The activities involved in the process are: developing brand identity; identity implementation-determining the part of the identity to be communicated to the target audience and how it is to be done; managing the brand over time-managing the brand through its life cycle may involve alteration of brand strategy but consistency in the marketing strategy is important; managing the brand portfolio-managing organization different brands and product categories as a system rather than pursuing independent brand strategies. The focus is to determine the structure, scope, roles and inter-relationship of the portfolio brands. Brand portfolio, when properly managed creates synergy and leverage that would build relevant, differentiated and energized brands. Leveraging the brand-it involves extending the core identity to a new product item in a product line or category. Its methods include: line extension, stretching the brand vertically, brand extension and co-branding, licensing; brand equity - the assets and liabilities that impact brand equity include brand loyalty, brand awareness, perceived quality, brand associations and proprietary brand assets (patents); strategic brand analysis-strategic analysis provides essential information for decision making for each of the brand management activities. The analysis includes market/customer, competitors and brand analysis.

The Thompson Total-plan developed by J. Walter Thompson is another strategic planning tool that operates on the basis of five (5) questions about the brand (Russell \& Lane, 1999). The five-step questions are: Where are we now? This involves market analysis of the brand appeal in consumers mind in relation to its competitors and its client's mind. Why are we there? This means the reason for the brand's current image. This step helps to identify brand visions which will guide brand's communication activities. Where could we be? Here the organization puts itself in the position of the consumers shoe to identify the most powerful connection between the brand and the consumer. The end product is the brand vision. How can we get there? This step helps to identify the brand idea, the creative expressions of the brand vision to target audience. Are we getting there? This has to do with brand performance evaluation on the accomplishment of set objectives and how to improve next time.

Another strategic management model evaluating brand life cycle is the Avrett Free and Ginsberg's seven steps planning cycle (Russell \& Lane, 1999). This model, if properly applied, will help to achieve long term growth and brand equity. The framework (SWOT analysis) involves the following steps. First, brand/market status; second, brand mission/goals (future destination of the brand); third, strategic development; various options are evaluated to determine the strategy that will help to achieve the brand mission; fourth, Strategy; this involves strategy formulation that will be used in designing integrated marketing communication program; fifth, creative exploration; brand valuation, tracking marketplace performance and progress to modify communication strategy to suite changing market conditions; and sixth, brand vision; brand equities generated through effective communication are often evaluated for long range expansion plan in terms of product line extension or concentric diversification in related categories. We have explored some of the approaches to developing integrated strategic plan for the PSC brands. In the next following section, we shall take a look at their extension to the development of destination (nation) brands.

Based on the adaption of corporate branding theory, Hankinson (2007) developed five principles as strategy for the management of destination brands. The principles are: first; strong, visionary leadership; second, a brand-oriented organizational culture; third, department co-ordination and process alignment; fourth, consistent 
communications across a wide range of stakeholders; and fifth, strong, compatible partnerships. Another corporate branding theory that can been applied in nation branding is the highest central common factor (HCCF), a four stage corporate brand differentiation process that starts with a review of corporate characteristics present in the firm's diversified business portfolio; followed by the identification of characteristics common to all business portfolio, thirdly, an internal assimilation of the characteristics and lastly, the presentation of the characteristics to the external stakeholders by different kinds of Integrated Marketing Communications (IMC) tools (Otubanjo \& Melewar, n.d).

Brand architecture is a concept in brand theory which can be applied in nation branding. It is an organizing structure of the brand portfolio that determines the roles and the relationships among brands and different product-market brand contexts (Aakar \& Joachimsthaler, 2000). Olins (1989) distinguished between three basic brand portfolio structures: the monolithic structure - a single dominant corporate umbrella brand; the endorsed structure - individual brands with their individual names and identity but clearly endorsed by the parent brand; and the branded structure - individual brand identity stand alone without endorsement of parent brand. Table 1 represents a more comprehensive model outlines the various stages of operational plan of nation branding.

Table 1. Country brands: the operation plan's main stages

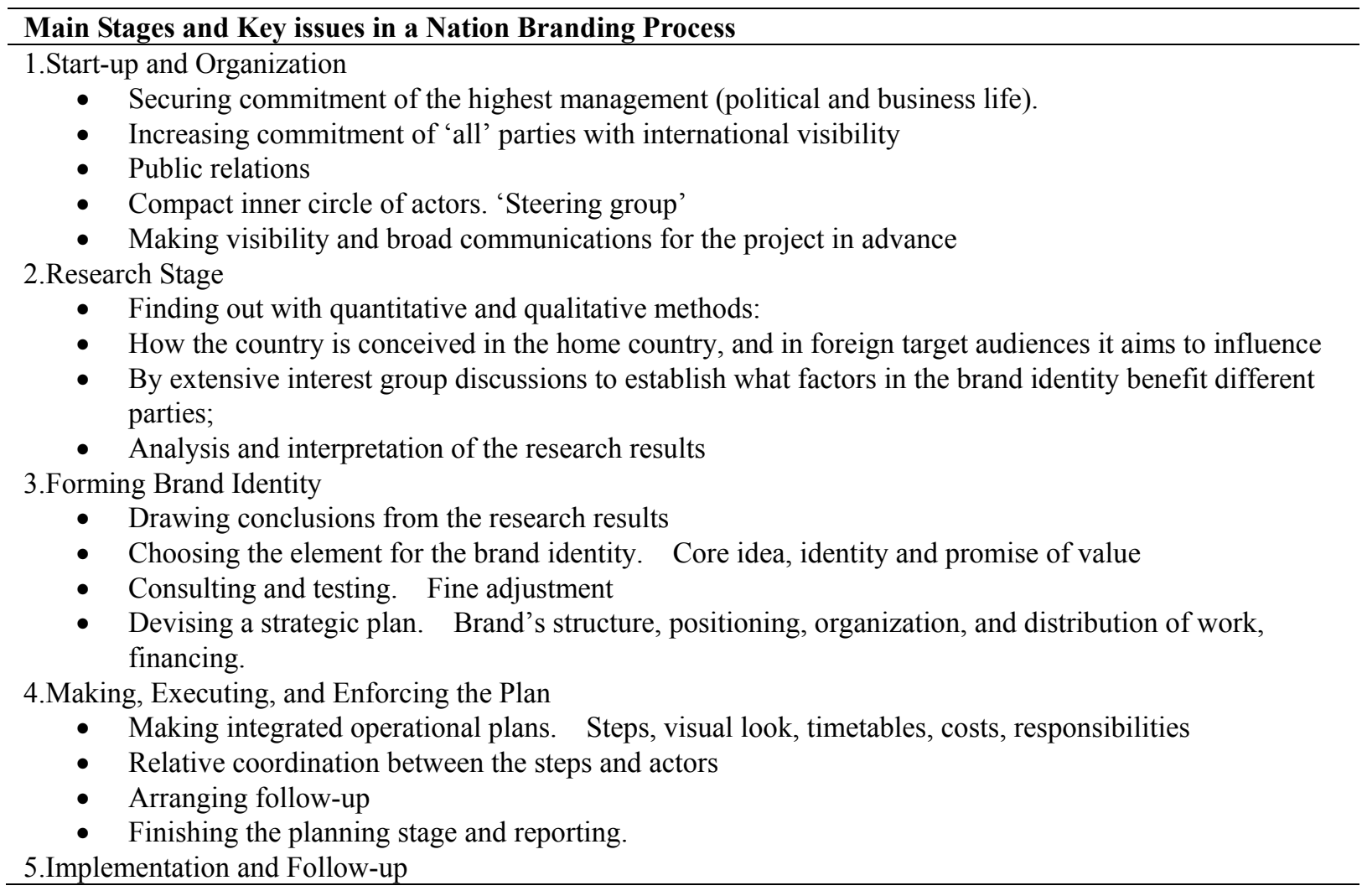

Source: Moilanen, T., \& Rainisto, S. (2009). How to brand nations, cities, and destinations UK: Palgrave Macmillian.

\subsection{The Nigeria Brand Image}

A review of the existing literature on the image of the Nigeria brand is undertaken in this section. This review is done on the basis of key determinants of a nation brand image.

\subsubsection{Telecommunication Sector}

In Nigeria, the telecommunication industry witnessed a tremendous growth with the largest GSM market in Africa since the advent of GSM in since 2001 (Ndukwe, 2004; Kenneth, 2007). This sector appears to have improved the nation's GDP as its contributions increased from $0.32 \%$ in 2000 to $3.66 \%$ in 2009 (NCC, 2012) and generated over 200 billion Naira (Adeyinka, Ajiboye, Adu, \& Wojuade, 2007).

\subsubsection{Hospitality}

On hospitality index, Nigeria has been adjudged in an international poll organized by the UK New Scientist 
magazine as the most friendly and happiest people on earth. The study of Odia (2012) also indicated that among the various indices used in evaluating the Nigeria brand image, hospitality index ranked highest.

\subsubsection{Population}

The population of Nigeria growing at 3.2 per cent per annum is projected to increase from 160 million in 2006 to 170 million in 2013 (Subair, 2013). Nigeria's population has been acknowledged as the largest market in Africa (Nworah, 2007).

\subsubsection{Raw Material Resources}

Nigeria is endowed with numerous natural resources. For instance, she has great potential to produce enough sugar that could earn the country a lot of foreign exchange if the resources are properly harnessed (Wada, Gbabo \& Akinsanya, 2001). Presently, only about $1 \%$ of the national sugar requirement of about 1 million tons annually is produced (Wada et al., 2001). Aside Sugar, cowpea/soybean, cassava and the aquaculture system resources are common in Nigeria. Nigeria is endowed with abundant resources that could support the development of the iron and steel industry. Some of the most important ones are iron ore, coal, dolomite, limestone, refractory, clays, ferro-alloys, etc. Nigeria is known to possess about 1.3 billion tonnes of coal deposits in Enugu, Kogi and Nassarawa States; 25billion barrels of petroleum and natural gas in Delta, Rivers, Bayelsa, Cross River and Imo State; bituminous tar sand in a belt which runs approximately east-west from Ondo state to Ogun state; radioactive minerals in Plateau, Gombe and Sokoto states (Ibrahim \& Biliaminu, 2010). Outside these, Nigeria is also rich in other natural resources such as cotton, cocoa, and groundnuts.

\subsubsection{Energy Supply}

Arobieke, Osafehinti, Oluwajobi and Oni (2012) observed that Power Holding Company of Nigeria PHCN) hardly meet the electricity needs of users as supply $(3,600 \mathrm{MW})$ is always less than demand $(7,600)$. The high cost involved in running generators has been attributed for the exit of Michelin Plc which cost the Nigerian economy 1,300 direct jobs (George \& Oseni, 2012).

\subsubsection{Educational System}

A report by Obe (2007) indicated that out of the 25 federal owned universities, 18 were found to have over enrolled and that, 13 out of 19 state universities shut above their capacities while only one of 7 private universities enrolled above its capacity. The Nigerian government hardly ever meets UNESCO's recommendation that all countries should allocate not less than 26 per cent of their annual budget to the educational sector. In 2000 , the Nigerian government allocated $8.36 \%, 7 \%$ in $2001,8 \%$ in $2002,7 \%$ in 2003 , $12 \%$ in $2004,11 \%$ in $2005,11 \%$ in $2006,8 \%$ in 2007 and $13 \%$ in 2008 (Okocha, 2008). The abysmal performance in the Nigerian education sector can be judged from the poor rating of its universities. Only five Nigerian universities were rated among the first 100 top African Universities in 2006. The best Nigerian university OAU ranked $44^{\text {th }}$ behind some universities in Kenya, South Africa and Ghana (Onojeta, 2008).

\subsubsection{Security in Nigeria}

In recent times, Nigeria has witnessed increasing number of security problems which are diverse and complex, ranging from political, socio-economic agitations, ethno-religious crises, cultism, ransom kidnapping to 'Boko Haram' suicide bombers. The Minister of Police Affairs, Ibrahim Yakubu Lame reported that in 2008, 353 peoples in Nigeria were kidnapped with 2 death cases; while in 2009, 512 cases of kidnapping were reported, out of which 30 died (Lame, 2009). Clayton Consultants (2009) describes Nigeria as world's top 8 kidnapping hotspots. Shell Petroleum reported that 133 of its employees were kidnapped between 2006 and 2008 (Shell, 2009).

\subsubsection{Inordinate Desire for Imported Goods}

Another major feature of many Nigerians is the over-dependence on foreign goods ranging from foreign names, clothes, foods, spouses, musical, technology, institution, tourist centres to television programmes (Agbonifoh (1986). In the study of a Nigerian automobile assembly company, Jaffe and Nebenzahl (2001:3) found that Nigerians prefer foreign, high-technology products to locally assembled Peugeot 504 as its sales decreased from 100,000 units in 1986 to about 4,500 units in 1996 when import restrictions were eased.

\subsubsection{Bribery and Corruption}

Corruption in Nigeria puts everyone at risk. Olaniyan (2006) in a remark stated that "corruption tarnishes our brand image and compromises our values and reputation. It erodes our equity..." According to Nuhu Ribadu, chairman of the EFCC, over $\$ 400$ billion was been looted from the country which six times the amount spent in rebuilding Western Europe at the end of the Second World War (Akubor, 2011). According to the Transparency 
International Corruption Perceptions Index, Nigeria ranks the 'most corrupt' three times in 1996, 1997 and 2000; the second most corrupt four times in 1999 and 2001-2003; the third most corrupt two times in 2004 and 2005; the fourth most corrupt in 1998; and lastly the fifth most corrupt in 2006 (Aluko, 2006).

\subsubsection{Level of Poverty}

According to World Bank Statistics (2004), about $66 \%$ of the population now falls below the poverty line of about one dollar a day compared to $43 \%$ in 1985 . Sharing the views of others, Larmode (2008) speaks on resources from oil and poverty level: "we made nearly half a trillion dollar from oil in less than five decades, a figure that dwarfs the international aid to the whole Africa, yet around 70 percent of our citizens live in conditions of dispiriting poverty on income less than a dollar a day." Poverty rates in Nigeria by region as obtained from National Bureau of Statistics are as following: South East 26\%, South-South 35.1\%, South West 43.0\%, North Central 67.0\%, North West 71.2\%, North East 72.2\%, and Nation 54.4\%. To attract Foreign Direct Investment (FDIs) into the country, there is need to develop the nation's wealth index.

\section{Methods}

This study relied heavily on secondary source of data and information to decipher the image of the Nigeria brand. The analysis of the Nigeria environment was carried out on the basis of some selected key elements of a nation's brand image by adopting a combination of Anholt's (2007) Nation Brand Hexagon; Dinnie's (2008) NBEQ model and PEST model. PEST is an acronym for the Political, Economic, Socio-cultural and Technological environment. The discussion and policy implication were undertaken by means of a proposed Nation Brand Strategic Management (NBSM) model. The NBSM model constructed in this work was done after a careful review of the following strategic management models by Moilanen and Rainisto (2009), Aakar (1991); Avrett Free and Ginsberg's seven steps planning cycle and the Thompson T-plan by J. Walter Thompson.

\section{Findings, Discussion and Policy Implication}

The review of the existing Nigeria brand image unearths Nigeria's areas of strength to be in telecommunications, presence of raw materials, large population and hospitality. Notwithstanding the challenges facing Nigeria in the areas of energy, security, corruption, and education, it is our hope that the proposed NBSM model will help to overcome the identified challenges and reposition the image of Nigeria in the world map. 


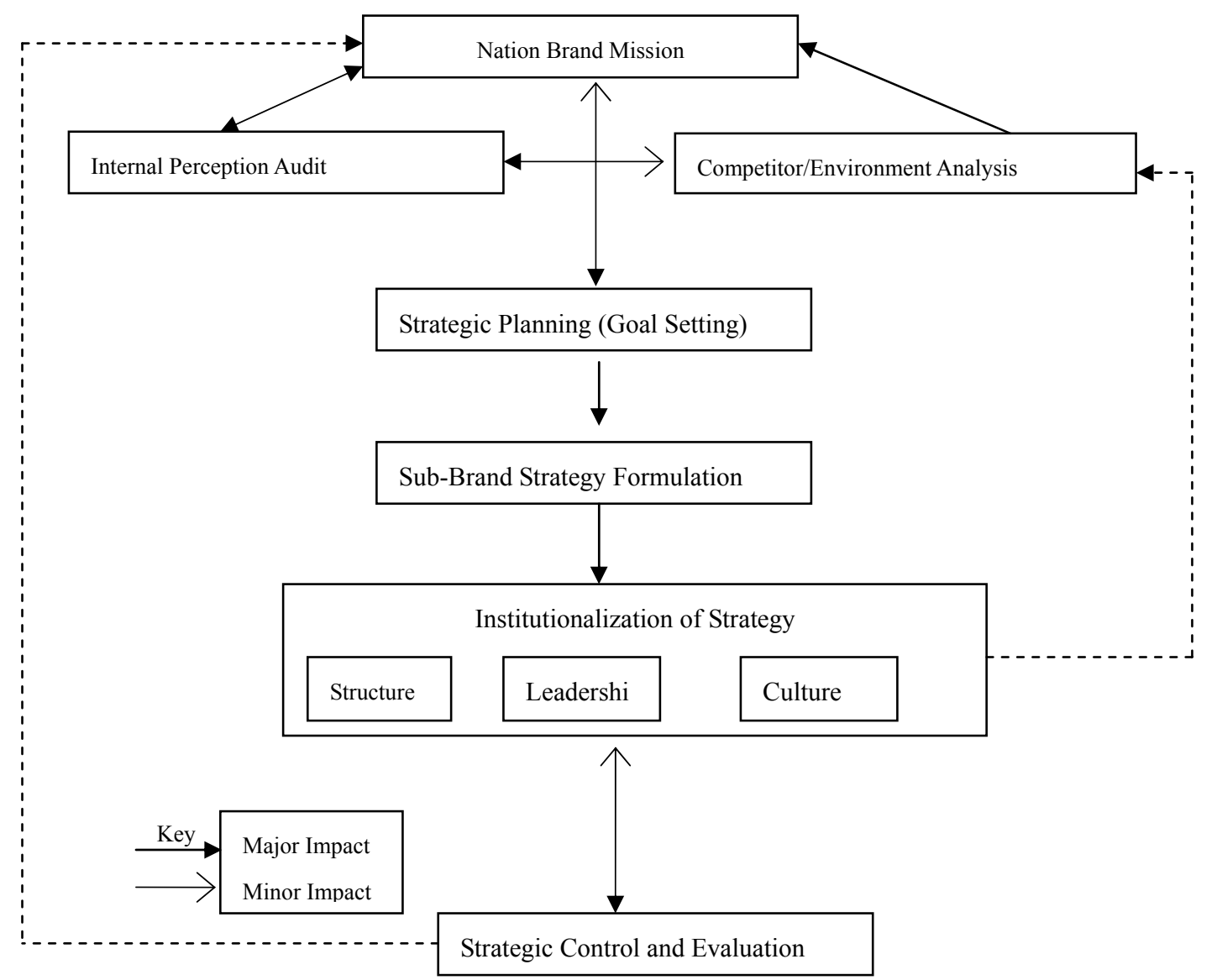

Figure 1. Nation brand strategic management model

Source: Authors' Construction.

\subsection{Nation Brand Vision/Mission}

The mission is the nation's philosophy, an enduring statement of nation intent. The vision is the future direction for the brand, its future roles and status (Roll, 2007). Nigeria brand vision may be to improve its perceptual position/image; strengthen the nation's economic performance in terms of exports, inward investment and tourism in addition to making Nigeria a world class content superpower.

\subsection{Internal/External Perception Audit}

The importance of public perception audit cannot be over-emphasized in effective nation branding. Perception audit involves extensive desk research, in-depth interviews with the Nigerian political and opinion leaders, entrepreneurs and journalists, a comprehensive audit of Nigeria's existing visual identity, focus-group sessions with Nigerian and non Nigerian business people, telephone interviews within Nigeria and a further interviews with tourists, investors and importers in target countries, team participation in several public panels and conferences on national identity and lastly, input from artists, designers, marketing professionals, researchers and public and private officials, civil society in Nigeria. We suggest that the brand vectors given in Table 2 may be applied in conducting nation brand perception. 
Table 2. A framework of brand vectors for evaluating a nation's image

\begin{tabular}{|c|c|c|c|c|c|}
\hline \multicolumn{3}{|c|}{ Commercial Nation Sub-Brands } & \multicolumn{3}{|c|}{ Non-Commercial Nation Sub-Brands } \\
\hline Investment & Exports & Tourism & Governance & Culture & People \\
\hline $\begin{array}{l}\text { Power supply/ } \\
\text { technological } \\
\text { advancement }\end{array}$ & $\begin{array}{l}\text { Quality of locally } \\
\text { made products: }\end{array}$ & $\begin{array}{l}\text { The peoples' } \\
\text { attitudes to visitors }\end{array}$ & $\begin{array}{l}\text { Electoral system } \\
\text { in the country }\end{array}$ & $\begin{array}{l}\text { Quality of } \\
\text { music/movies }\end{array}$ & $\begin{array}{l}\text { Friendliness and } \\
\text { hospitality of the } \\
\text { people }\end{array}$ \\
\hline Educational system & Durable & $\begin{array}{l}\text { Climate/weather } \\
\text { condition }\end{array}$ & $\begin{array}{l}\text { Attitude to human } \\
\text { right issues }\end{array}$ & $\begin{array}{l}\text { Music/Movies as } \\
\text { ambassadors }\end{array}$ & $\begin{array}{l}\text { Quality of the } \\
\text { Diaspora }\end{array}$ \\
\hline $\begin{array}{l}\text { Health care } \\
\text { Economic stability }\end{array}$ & $\begin{array}{l}\text { Value for money } \\
\text { (Price) }\end{array}$ & $\begin{array}{l}\text { International image } \\
\text { of Tourism }\end{array}$ & $\begin{array}{l}\text { Foreign policies / } \\
\text { domestic } \\
\text { laws/policies }\end{array}$ & $\begin{array}{l}\text { International } \\
\text { sporting } \\
\text { performance }\end{array}$ & $\begin{array}{l}\text { Sport stars as } \\
\text { brand } \\
\text { ambassadors }\end{array}$ \\
\hline $\begin{array}{l}\text { Telecommunications \& } \\
\text { Transportation system }\end{array}$ & Fashionable & $\begin{array}{l}\text { Customer service } \\
\text { in the Hospitality } \\
\text { Industry }\end{array}$ & $\begin{array}{l}\text { Observance of } \\
\text { law }\end{array}$ & $\begin{array}{l}\text { Hosting } \\
\text { international } \\
\text { sports event }\end{array}$ & $\begin{array}{l}\text { Corruption } \\
\text { among the } \\
\text { people }\end{array}$ \\
\hline Cost of doing business & Reliable & $\begin{array}{l}\text { International } \\
\text { airport's image }\end{array}$ & $\begin{array}{l}\text { Respect for the } \\
\text { minorities }\end{array}$ & $\begin{array}{l}\text { Landscape's } \\
\text { attractiveness }\end{array}$ & $\begin{array}{l}\text { Inventiveness of } \\
\text { the people }\end{array}$ \\
\hline $\begin{array}{l}\text { Tax incentive for } \\
\text { business investors }\end{array}$ & $\begin{array}{l}\text { Workmanship/ } \\
\text { craftsmanship }\end{array}$ & $\begin{array}{l}\text { Safe place for } \\
\text { tourism }\end{array}$ & $\begin{array}{l}\text { Corruption level } \\
\text { in government }\end{array}$ & $\begin{array}{l}\text { Literatures as } \\
\text { ambassadors }\end{array}$ & $\begin{array}{l}\text { Industriousness } \\
\text { of the people }\end{array}$ \\
\hline $\begin{array}{l}\text { Availability of raw } \\
\text { materials \& skilled } \\
\text { labour }\end{array}$ & $\begin{array}{l}\text { International } \\
\text { position of locally } \\
\text { made products }\end{array}$ & $\begin{array}{l}\text { The nation's } \\
\text { cultural } \\
\text { heritage/landscape }\end{array}$ & $\begin{array}{l}\text { Level of } \\
\text { transparency in } \\
\text { government }\end{array}$ & $\begin{array}{l}\text { International } \\
\text { image of } \\
\text { literatures }\end{array}$ & $\begin{array}{l}\text { Level of poverty } \\
\text { among the } \\
\text { people }\end{array}$ \\
\hline Safety/Security & Product uniqueness & Festivals & Judicial system & & \\
\hline $\begin{array}{l}\text { Honesty in business } \\
\text { practice }\end{array}$ & $\begin{array}{l}\text { Made-in labels; } \\
\text { Country-of-Origin } \\
\text { effect }\end{array}$ & $\begin{array}{l}\text { The nation's } \\
\text { history/arts }\end{array}$ & Political stability & & \\
\hline $\begin{array}{l}\text { Attitudes to work and } \\
\text { maintenance culture }\end{array}$ & $\begin{array}{l}\text { Loyalty to locally } \\
\text { made products }\end{array}$ & $\begin{array}{l}\text { Advancement in } \\
\text { tourism }\end{array}$ & & & \\
\hline $\begin{array}{l}\text { Business registration } \\
\text { procedures }\end{array}$ & $\begin{array}{l}\text { Product's } \\
\text { technological } \\
\text { advancement }\end{array}$ & $\begin{array}{l}\text { International } \\
\text { perception of the } \\
\text { tourism }\end{array}$ & & & \\
\hline $\begin{array}{l}\text { Residency criteria (for } \\
\text { visa and passport) }\end{array}$ & $\begin{array}{l}\text { Product appearance } \\
\text { vs. performance }\end{array}$ & & & & \\
\hline
\end{tabular}

Adapted from: Anholt's (2007) Nation Brand Hexagon; Dinnie's (2008) NBEQ and PEST model.

Table 2 is an attempt to make a comprehensive list of all key vectors through which nation brands express their images. Apart from the internal audit, there is also the need to perform external analysis to ascertain the nation's (Nigeria) present competitive position in the global market. Competitor analysis focuses on key questions such as: Who are our competitors? What are their strengths and weaknesses? What are their strategic goals and strategies? (Jobber, 2004). Dinnie (2008) developed a Nation-brand competitor analysis matrix, a tool for analyzing the nation-brand's competitiveness across the key dimensions of nation-branding activity. The analysis should be done with a view to determining competitor's strengths, weaknesses, strategic goals and current strategies in area such as tourism, FDI, exports and talent attraction.

\subsection{Strategic Planning (Goal Setting)}

Goals for a country may be set in terms of any of the sub brands. For Nigeria, the following long-term goals may be set to be achieved from 5 years and above. The goals could be to: improve Nigeria brand image; international relations; national gross income figure (financial brand value); and quality of made-in-Nigeria products; provide peaceful atmosphere for tourists, create most sought investment destination and a resourceful place for study (especially for foreigners); achieve international recognition in sports; promote local foods and fashion in the international market; and reduce incidence of corruption among public office holders.

\subsection{Sub-Brand Strategy Formulation}

The internal and external strategies used by the corporate organizations can also apply to nation brands with modification. By means of penetration strategy (operating in existing local and international markets), market development (expansion into international markets), joint venture-co-branding by two nations (Aakar, 1996; Dinnie, 2008), concentric diversification (development of inward investment and exports) or conglomerate 
diversification (all or some of the sub-brands combined) can be developed by the Nigeria brand team. By defining its brand scope and segmentation strategies, Nigeria can effectively compete on any of the following sub-sectors discussed below.

\subsubsection{Investment Sub-Brand Strategy}

For the Nigerian government to be able to attract foreign investors, we advocate that the administrative procedure for business registration should be made simple and less bureaucratic. With enhanced registration procedure, promotional campaigns by Nigerian Investment Promotion Commission (NIPC) such as the current campaign on "one stop investment in Nigeria" can be designed to create benefit awareness for the Nigerian investment sector. Since the goal of the promotional campaigns is to raise economic profile of Nigeria, then the leading target investment countries must be identified and promotional messages tailored to meet their needs. Tangible facts and testimonials involving executives from international corporations already doing business in Nigeria would be of assistance in attracting investors from the target country. The focus of the message would be for the selected executives to describe their success firsthand to underline the ease of starting and operating a business in Nigeria and also to emphasize its flexible labour laws and tax rates. Issues relating to cost of doing business can be addressed through investment in efficient and modern infrastructure such as good road networks, transportation facilities and energy supply.

\subsubsection{Exports Sub-Brand Strategy}

By borrowing a leaf from South Korea's experience, the Nigerian government can set up a multi-billion naira venture fund to help exporters improve the designs of their products. Additionally, industrial design renovation centres can be set in selected major cities nation-wide to help SMEs in the design of their products. Also, efforts should be made to enhance infrastructure by funding a 'Brand Academy' to train reasonable number of specialists every year on brand management, character design and industrial packaging.

National stakeholders should be persuaded to use the national 'umbrella brand' name/logo/flag/language/icons in their individual marketing communications. Local manufacturers and exporters should help to project the nation by incorporating the country's brand values (this could be in the form of national logo on packaging, the use of country imagery on point of sale materials and on websites. Before deciding on the Nigeria brand architecture (Olins', 1989), the mother brand and sub-brand equities must be evaluated to determine their current contribution and potential value. Querrilla marketing, ambient marketing and tone and visual style of communications may be adopted to market the nation's branded exports. International sales promotion may be helpful in creating Nigeria brand awareness.

\subsubsection{Tourism Sub-Brand Strategy}

Major actors in the tourism industry must unanimously come together to target markets and business strategies to actualize their goals. There should be a level play ground for all actors to be involved in the branding process, not for it to be hijacked by the biggest companies in the industry (brand identity and architecture). A consistent message should be developed by members over time; that is, the need for a consensus on brand's content (values, needs and basic message). The Tourist Board should design a process to imbue the employees of tourist centres and travel agencies with the values of friendliness, honesty, and good organization. There should be an alignment between the values of the Nigeria brand and the personality of the Tourism Board. Just like Egypt, Nigeria can increase her GDP immensely by developing its tourism.

\subsubsection{Education and Talent Attraction Sub-Brand Strategy}

Nigeria, like UK can benefit immensely from marketing its education brand globally just as UK did through www.uk.universities.ac.uk, the British council, the Department for International Development (DFID), UK Embassies and Education Fairs by Universities in the UK and overseas (Nworah, 2007). But the first step in turning the educational system around is through adequate funding and provision of facilities and infrastructures. Government's incorporation of private participation in education is a welcomed idea, provided people of integrity are continually drafted into the National Universities Commissions (NUC) to ensure quality assurance.

\subsubsection{Arts and Culture Sub-Brand Strategy}

In support of Yusuf's (2009) advice, Nigerians must learn to appreciate their cultural wealth by patronizing them. The role of the Nigerian Government in exploring culture as a tool for veritable rebranding would be to set up a Task Force consisting of members from bodies like the Executive of National Institute for Culture Orientation (NICO); National Gallery of Art (NGA); National Film and Video Censor Board (NFUCB); National Council for Arts and Culture (NCAC) and others that would help to integrate culture into national identity. A unit under the established Task Force could be responsible for managing media content of the locally produced music, 
movies, game software and animation. For Nigeria to become a world-class contents super power as exemplified by countries like America, UK and Japan, there should be establishment of content archives, fair compensation for content creators to encourage them exhibit their skills; development of human resources in the contents fields and reward of outstanding content in addition to establishment of National University of Fine Arts and Music (Dinnie, 2008). There is also the need for enforcement of Copyright Laws to protect local brands. Furthermore, to compete effectively on the global stage, public funds should be made available to contemporary singers and music bands to tour abroad.

Incorporation of sports into the nation-branding mix can be used as a positioning tool. The hosting of international sports events such as Olympic game or FIFA world cup can be of great assistance in reimaging Nigeria in the international stage. Through sonic branding, the local musicians in Nigeria can be brought together to create authentic, spirited and traditional style music that can be played by full orchestra during international sporting events and nation days. Nigerian novels, poetry, plays and other forms of literatures represent deeper and richer route into the country's core purpose (Anholt, 2007; Dinnie, 2008). They are also means by which Nigeria can express her culture, psyche and identity. They also act as state of the art pronouncements. The literary outputs used in coordinated synergistic form should aid in boosting a nation's tourism and exports. Festivals in Nigeria can also be explored to attract tourist. Examples are: Obanta Day in Ijebu Ode, IIa Oso Uzuakoli in Abia state, Ekpe Masquerade Days in Umuahia and Akwa Ibom and Igue Festival in Benin Kingdom.

\subsubsection{The People Sub-Brand Strategy}

A nation with limited financial resources can benefit greatly from activation of the Diaspora (Dinnie, 2008). The Diaspora is useful in terms of remittances (poverty alleviation), stimulation of FDIs through intervention be well-placed senior executives in international firms. It can further be used as bridges and antennae for the development of projects in Nigeria. Nigeria can reposition its image by using celebrity endorsers who are professional in their own fields.

Nigeria's hospitality opens up employment opportunities for its citizens in multinational companies within and outside the country. It also helps the Diaspora to attract visitors and investors into the country. For example, countries like China obtained $70 \%$ of FDI from the its diaspora while Haiti and Jordan both received about 20\% of their GDP from diaspora connection (Torries \& Kuznetsor, 2006). This advantage of being hospitable appears to have been grafted into Nigeria's existing promotional campaign slogan: "Good People Great Nation." To sustain this core value, continuous efforts should be made by parents, religious bodies and others to evolve a more practical way of inculcating virtues of being friendly, respectful and honest in our children right from infancy.

\subsection{Strategic Implementation}

In respect of Nigeria brand promotion, a campaign comprising of international/local advertising, public relations, government relations, and event planning can be developed to raise its profile. As part of public relation, arrangement of events abroad through working with public relation firms for extensive professional media coverage should be explored. Third party endorsement, events management, efficient media relations, study tours for the foreign press, and road shows organized by Nigerian embassies to attract investment should be among the most frequently used public relations tools.

Nation brand advertising as a powerful tool for communicating the values of Nigeria brand might begin with intensive print ad campaign, some in international economic publication in target country audiences; other may involve the use of large billboards in international airports. Yet others could be on the internet in the form of banner ads on leading economic websites such as NIPC.gov.ng. However, a coordinated and consistent message should be related about the country. Efforts should be made to avoid bland information-heavy ads that fail to break through the advertising clutter. Ads can be run in different media channel and vehicles. An evaluation of the ad's effectiveness should be undertaken to aid modifications.

As an emerging nation, Nigeria would immensely benefit from the use of on-line branding as a niche brand. NIPC is already using this strategy through "NIPC.gov.ng". By using seeding trials, viral advertising, brand advocacy programme and influencer outreach initiatives as elements of on-line branding, the Nigeria brand team would be able to stimulate positive word-of-mouth. Nigeria brand team can consider the use of social networking sites as a component of its overall strategy. As a way of using third party endorser, foreign tourists should be encouraged to publish blogs on their tourism experiences in Nigeria.

By adopting the concept of co-branding, Nigeria should emulate Austria-Switzerland and Poland-Ukraine who 
hosted the European Football Championship in 2008 and 2012 respectively (Dinnie, 2008). The use of brand ambassadors with positive attributes that truly reflect the personality of Nigeria should be adopted. Just as Roger Federer of Switzerland and Ronaldo of Brazil, literary icons such as laurete Prof Wole Soyinka, late Prof. C. Achebe; Prof. Philip Emeagwali and Gabriel audu Oyibo; and footballer like Kanu Nwankwo, Yakubu Aiyegbeni, Obafemi Martins and Austine Jay Jay Okocha and other Nigerian celebrities like Nuhu Ribadu, Dora Akunyili, Ngozi Okonji Iweala, El Rufai, Oby Ezekwesili and late King Fela Kuti could be used in promoting the Nigeria brand internally and externally. Nigeria, irrespective of its present negative image can benefit from ambi-brand strategy utilized by Kenya and Northern Ireland (Dinnie, 2008).

\subsection{Institutionalisation of Strategy}

Strategies, whether in respect of a business organization or nation, are often institutionalized through: structure, culture and leadership. Given the multi-dimensional nature of nation brand, we recommend the Strategic Business Unit (SBU) structure. Operating SBU structure means each sub-brand can develop its image that would add up to the entire country's image. For effective leadership, a functional and credible organization known as the Steering Group (SG) or coordinating team should be convened by the government. Members of SG (around 20 people) are selected from parties with international visibility, including export industry, tourism, public diplomacy, science and sports, and political leaders (Molanen \& Rainisto, 2009). The SG would be responsible for developing the nation brand vision and coordination of the activities of the various sub-brands and reports to the office of the presidency. In building a nation brand, internal branding process must be put in place to elicit the commitment and buy-in of the full range of stakeholders. On the issue of internal branding, urban-rural dichotomy, multi-ethnic compositions, cultural, language, and religious differences should be taken into consideration (Dinnie, 2008). The objectives of the nation brand must be communicated in transparent manner both to the internal and external stakeholders. Following the experience of France brand, intermediate success stories and testimonials from relevant sources should be relayed from time to time. The challenges should also be made known to all stakeholders. Training sections should be organised for branding team to enable them carry out basic branding tasks.

Cultural strategies that need to be emphasized are: nation day celebration and celebration of historical figures. Nation day celebrations are potential elements for implementing nation brand strategy both internally to generate interest and pride in the nation's citizens and also externally as event to promote the nation. Nation day feast outside the country is better located in places with significant presence of the nation's diaspora. Other cultural ties include emphasis on the use of local fashion especially on Fridays by workers and as uniforms for school children as well as character building for the nation's youth from the home front, religious organizations should imbibe honesty and integrity. Other areas of culture that are important are: value, belief and attitudes of the people. For example, maintenance culture, attitudes to work, attitudes to visitors, attitudes to made-in-Nigeria products, honesty in business practice, transparency in policy formulation and execution and the people's internal locus of control.

\subsection{Strategic Control and Evaluation}

Strategic control tool can be used by nation brand management to monitor on-going activities of the nation and its sub-brands to evaluate whether activities are being performed efficiently and effectively and to take corrective action to improve performance if they are not. For Nigeria brand, performance standards could be set in the following areas: quality of made-in-Nigeria, number of tourists; level of foreign direct investments, inflation rate, interest rate, quality of university graduates, energy supply, level of infrastructure, level of GDP and GNI, technological advancement, media image and crime rate. Control strategies open to Nigeria brand management may include: monitoring agencies such as Economic and Financial Crime Commission EFCC and Independent Corrupt Public Offences Commission (ICPC); National Agency for Food and Drug Administration (NAFDAC); trade associations (e.g., Manufacturer Association of Nigeria); crime combating commission (e.g. the Police Force); revenue and expenditure budgets and capital budgets. In conclusion, if Nigeria scores highly on any of the set standards, then it should be highlighted and communicated to the stakeholders to boost the achievement of objectives such as increasing FDI, talent attraction and others. When there are deviations, they should be fixed by continuous improvement.

\section{Conclusion}

The attempted review of the extant literature showed that the current image of the Nigeria brand is more on the negative side, particularly in the area of energy supply, security, corruption and education. Having considered nation branding models designed by other branding experts, we proposed a strategic management model for managing a nation's brand image. The study also demonstrated the application of the constructed model in the 
management of the Nigeria brand. While minimizing the menace of insecurity and corruption, Nigeria can greatly benefit from marketing of its cultural tourism. Additionally, improvement in the Nigeria's energy supply will help to attract foreign investors that would bring about the efficient utilization of the nation's natural resources. A framework of nation brand vectors highlighting the key variables for perception audit was designed. Further empirical research that would utilize the proposed framework in determining the image of the Nigeria brand is recommended. It is our hope that if our recommendations are effectively applied, Nigeria will improve its competitiveness on the global stage.

\section{References}

Aakar, D. A. (1991). Managing brand equity. New York: Free Press.

Aakar, D. A. (1996). Building strong brands. New York: Free Press.

Aakar, D. A., \& Joachimsthaler, E. (2000). Brand leadership. NY: The Free Press.

Adeyinka, T., Ajiboye, J. O., Adu, O. E., \& Wojuade, J. I. (2007). Stakeholders' perceptions of the impact of GSM on Nigeria rural economy: Implication for an emerging communication industry. The Journal of Community Informatics, 3, 1-17.

Agbonifoh, B. A. (1986). Consumer preference and product origin: A study of consumer attitudes toward home-made and foreign-made products. Unpublished PhD. Thesis, Department of Business Administration, University of Benin, Benin City.

Akubor, E. O. (2011). Civil unrest in northern Nigeria: Beyond the literal "Boko Haram". The Constitution, 11(4), 71-93.

Akunyili, D. (2009). We cannot grow in an atmosphere of corruption. Tell Magazine, 13, 20.

Aluko, M. E. (2006). Nigeria-10 years of transparency international monitoring Nigeria's corruption. Retrieved from http://nigeriavillagesquare.com/nigeria-10-years-of-ti-monitoring.html

Anholt, S. (2007). Competitive identity: The new brand management for nations, cities and regions. UK: Palgrave Macmillan.

Arobieke, O., Osafehinti, S., Oluwajobi, F., \& Oni, O. (2012). Electrical power outage in Nigeria: History, cause and possible solutions. Journal of Energy Technologies and Policy, 2(6), 18-23.

Brymer, C. (2003). Branding a country. Retrieved from http://www.interbrand.com

Clayton Consultants. (2009). Kidnapping culture in Nigeria on the rise. Retrieved from http://www.naijafeed.com

Cravens, D. W., \& Piercy, N. D. (2006). Strategy marketing (8th ed.). NY: Mc Graw Hill.

Dinnie, K. (2008). Nation branding: Concepts, issues, practice. UK: Elsevier Ltd.

Fasure, S. (2009, March). Good salesman with bad product. The Nation, 2.

Ferguson, R. (2001). Brand-name government. Retrieved from http//www.knowledgemarketing group.com

George, E. O., \& Oseni, J. E. (2012). The relationship between electricity power and unemployment rates in Nigeria. Australian Journal of Business and Management Research, 2(2), 10-19.

Hankinson, G. (2007). The management of destination brands: Five guiding principles based on recent developments in corporate branding theory. Journal of Brand Management, 14, 240-254. http://dx.doi.org/10.1057/palgrave.bm.2550065

Ibrahim H. D., \& Biliaminu, K. O. (2010). Steel raw materials in Nigeria. A publication of Raw Materials Research and Development Council, Abuja. Retrieved from http//www.rmrdc.org

Jaffe, E. D., \& Nebenzahl, I. D. (2001). National image and competitive advantage: The theory and practice of country-of-origin effect. Copenhagen: School Press.

Jobber, D. (2004). Principles and practice of marketing (4th ed.). UK: McGraw Hill.

Kenneth, O. N. (2007). The impact of GSM mobile phones on Nigeria. Publication of Ezine Articles. Retrieved from http://www.ezinearticles.com

Lame, I. Y. (2009, July). 512 Kidnapping in Nigeria this year. Daily Trust. Retrieved from http://www.naijafeed.com

Larmode, I. (2008, April). EFCC queries use of \$500 bill oil revenue, \$300 bill aid. Lagos: The Guardian. 
Leonard, M. (1997). Renewing our identity. London: Demo.

Moilanen, T., \& Rainisto, S. (2009). How to brand nations, cities, and destinations. UK: Palgrave Macmillian

National Bureau of Statistics. (2011). National Living Standard Survey. Retrieved from http://www.nigerianstat.gov.ng /index.php

NCC (Nigeria Communications Commission). (2012). Share of telecommunication services. Industry Statistics-Subscriber Data at a Glance. Retrieved from http://www.ncc.gov.ng

Ndukwe, E. C. A. (2004). Three years of GSM revolution in Nigeria. Retrieved from http://www.ncc.gov.ng/archive/speeches_presentation/EVC

Nworah, U. (2007). Rebranding Nigeria: Critical perspectives on the heart of Africa image project. MRL Journal, $1(1), 43-65$.

Obe, I. (2007). Fund and scholarship in tertiary institutions in Nigeria. University of Lagos, Nigeria.

Odia, E. O. (2012). Public perception of the Nigeria brand. Unpublished PhD. Thesis, Department of Business Administration, University of Benin, Benin City.

Okocha, S. (2008, Oct.). Insight into level of education decay in the country. Newswatch, Special Anniverary Edition, 21-24.

Olaniyan R. (2006). Demarketing corruption and decorrupting marketing: The marketing challenges in the anti-corruption crusade. Journal of Marketing, 1(3).

Olins, W. (1989). Corporate identity. UK: Thames and Hudson.

Onojeta, S. O. (2008). Contemporary issues in globalization and national development in Nigeria. Journal of Business Studies and Technology Development (JBSTD), 4(2), 107-112

Otubanjo O. B., \& Melewar, T. C. (n.d). Corporate brand differentiation in the financial services industry-Applying the highest central common factor concept to nation branding.

Riezebos, R. (2003). Brand management: A theoretical and practical approach, FT. UK: Prentice Hall.

Roll, M. (2006). Asian brand strategy: How Asia builds strong brands. USA: Palgrave Macmillan.

Russell, J. T., \& Lane, W. R. (1999). Kleppner's advertising procedure (14th ed.). New Jersey, US: Prentice Hall.

Shell, P. (2009, Dec.). Kidnapping culture in Nigeria on the rise. Daily Trust. Retrieved from http://www.naijafeed.com

Subair, G. (2013). Nigeria's population hits 170 million this year. National Population Commission. Retrieved from http://tribune.com.ng/news2013/index.php/en/component/k2/item/5336-nigeria-s-population

Torres, F., \& Kuznestsov, Y. (2006). Mexico: Leveraging migrants' capital to develop hometown communities, in Diaspora Networks and the International Migration of Skills: How countries can draw on their talent abroad. In Kusznestsov, Y. (Ed.), WBI Development (pp. 99-128).

Ujiagbedion, M. (2008). The heart of Africa project: A public relations disaster? Marketing Edge Issue, 16, 24.

Wada, A. C., Gbabo, A., \& Akinsanya, T. O. (2004). Indigenous brown sugar processing technology in Nigeria: Past and on-going research. Society for Sugar Research and Promotion (SSRP), 6(3).

World Bank Report. (2004). World development indictors. Retrieved from http://www.worldbak.org

\section{Copyrights}

Copyright for this article is retained by the author(s), with first publication rights granted to the journal.

This is an open-access article distributed under the terms and conditions of the Creative Commons Attribution license (http://creativecommons.org/licenses/by/3.0/). 